\title{
The acute and late toxicity results of a randomized phase II dose-escalation trial in non-small cell lung cancer (PET-boost trial)
}

Citation for published version (APA):

van Diessen, J., De Ruysscher, D., Sonke, J-J., Damen, E., Sikorska, K., Reymen, B., van Elmpt, W., Westman, G., Persson, G. F., Dieleman, E., Bjorkestrand, H., Faivre-Finn, C., \& Belderbos, J. (2019). The acute and late toxicity results of a randomized phase II dose-escalation trial in non-small cell lung cancer (PET-boost trial). Radiotherapy and Oncology, 131, 166-173. https://doi.org/10.1016/j.radonc.2018.09.019

Document status and date:

Published: 01/02/2019

DOI:

10.1016/j.radonc.2018.09.019

Document Version:

Publisher's PDF, also known as Version of record

\section{Document license:}

Taverne

Please check the document version of this publication:

- A submitted manuscript is the version of the article upon submission and before peer-review. There can be important differences between the submitted version and the official published version of record.

People interested in the research are advised to contact the author for the final version of the publication, or visit the DOI to the publisher's website.

- The final author version and the galley proof are versions of the publication after peer review.

- The final published version features the final layout of the paper including the volume, issue and page numbers.

Link to publication

\footnotetext{
General rights rights.

- You may freely distribute the URL identifying the publication in the public portal. please follow below link for the End User Agreement:

www.umlib.nl/taverne-license

Take down policy

If you believe that this document breaches copyright please contact us at:

repository@maastrichtuniversity.nl

providing details and we will investigate your claim.
}

Copyright and moral rights for the publications made accessible in the public portal are retained by the authors and/or other copyright owners and it is a condition of accessing publications that users recognise and abide by the legal requirements associated with these

- Users may download and print one copy of any publication from the public portal for the purpose of private study or research.

- You may not further distribute the material or use it for any profit-making activity or commercial gain

If the publication is distributed under the terms of Article $25 \mathrm{fa}$ of the Dutch Copyright Act, indicated by the "Taverne" license above, 
Original Article

\title{
The acute and late toxicity results of a randomized phase II dose-escalation trial in non-small cell lung cancer (PET-boost trial)
}

\author{
Judi van Diessen ${ }^{a}$, Dirk De Ruysscher ${ }^{b}$, Jan-Jakob Sonke ${ }^{a}$, Eugène Damen ${ }^{a}$, Karolina Sikorska ${ }^{c}$, \\ Bart Reymen ${ }^{\mathrm{b}}$, Wouter van Elmpt ${ }^{\mathrm{b}}$, Gunnar Westman ${ }^{\mathrm{d}, 1},{ }^{\mathrm{a}}$, Gitte Fredberg Persson ${ }^{\mathrm{d}}$, Edith Dieleman ${ }^{\mathrm{e}}$, \\ Hedvig Bjorkestrand ${ }^{\mathrm{f}}$, Corinne Faivre-Finn ${ }^{\mathrm{g}}$, José Belderbos ${ }^{\mathrm{a}, *}$
}

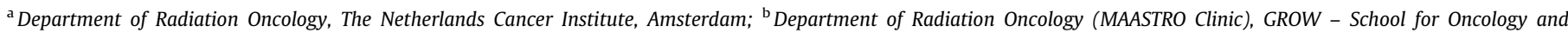

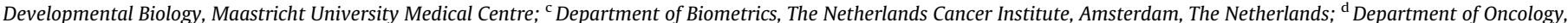

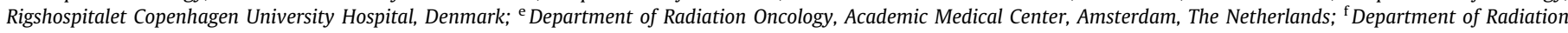
Oncology, Karolinska Institute, Stockholm, Sweden; ${ }^{g}$ The University of Manchester, Division of Cancer Sciences, The Christie NHS Foundation Trust, United Kingdom

\section{A R T I C L E I N F O}

\section{Article history:}

Received 1 March 2018

Received in revised form 24 September

2018

Accepted 25 September 2018

Available online 13 October 2018

Part of this work was presented as an oral communication during the 3rd ESTRO

Forum, 25-28 April 2015, Barcelona, Spain.

\section{Keywords:}

Dose-escalation

Non-small cell lung cancer

PET-boost

Toxicity

Dose painting

\begin{abstract}
A B S T R A C T
Background and purpose: The PET-boost randomized phase II trial (NCT01024829) investigated doseescalation to the entire primary tumour or redistributed to regions of high pre-treatment FDG-uptake in inoperable non-small cell lung cancer (NSCLC) patients. We present a toxicity analysis of the 107 patients randomized in the study.

Materials and methods: Patients with stage II-III NSCLC were treated with an isotoxic integrated boost of $\geq 72$ Gy in 24 fractions, with/without chemotherapy and strict dose limits. Toxicity was scored until death according to the CTCAEv3.0.

Results: $77(72 \%)$ patients were treated with concurrent chemoradiotherapy. Acute and late $\geq \mathrm{G} 3$ occurred in $41 \%$ and $25 \%$. For concurrent (C) and sequential or radiotherapy alone (S), the most common acute $\geq \mathrm{G} 3$ toxicities were: dysphagia in $14.3 \%(\mathrm{C})$ and $3.3 \%(\mathrm{~S})$, dyspnoea in $2.6 \%(\mathrm{C})$ and $6.7 \%(\mathrm{~S})$, pneumonitis in $0 \%(C)$ and $6.7 \%(S)$, cardiac toxicity in 6.5\% (C) and 3.3\% (S). Seventeen patients died of which in 13 patients a possible relation to treatment could not be excluded. In 10 of these 13 patients progressive disease was scored. Fatal pulmonary haemorrhages and oesophageal fistulae were observed in 9 patients. Conclusion: Personalized dose-escalation in inoperable NSCLC patients results in higher acute and late toxicity compared to conventional chemoradiotherapy. The toxicity, however, was within the boundaries of the pre-defined stopping rules.
\end{abstract}

(C) 2018 Elsevier B.V. All rights reserved. Radiotherapy and Oncology 131 (2019) 166-173
The majority of inoperable non-small cell lung cancer (NSCLC) patients have high loco-regional progression rates of approximately $30 \%$ at two years after treatment with concurrent chemoradiotherapy (cCRT) [1]. Standard chemo-radiotherapy for patients with a good performance status consists of at least $60 \mathrm{~Gy}$ in 6 weeks combined with cis- or carboplatin-based chemotherapy delivered concurrently [2]. A reduction of the overall treatment time (OTT) through the delivery of hypofractionated radiotherapy schedules, e.g. $66 \mathrm{~Gy}$ in 24 fractions in 5 weeks, improves both locoregional control and overall survival (OS) in locally advanced NSCLC [3-5]. The outcome of fit patients treated with modern radiotherapy regimes in combination with chemotherapy has improved in recent years with 3 -year OS rates of $30-40 \%$ [6]. It is

\footnotetext{
* Corresponding authors at: Department of Radiation Oncology. The Netherlands Cancer Institute, Plesmanlaan 1211066 CX Amsterdam, The Netherlands.

E-mail address: j.belderbos@nki.nl (J. Belderbos).

1 Retired.
}

promising that comparable survival rates have been reported after 5 years $[7,8]$.

Locoregional recurrences are predominantly observed within the primary tumour, and less frequently within the involved mediastinal lymph nodes [9-12]. Therefore, the local control rate may be improved by escalating the radiation dose to the primary tumour [13-16]. ${ }^{18} \mathrm{~F}$-fluoro-2-deoxy-glucose positron emission tomography (FDG-PET)-scans generate a biological target volume that can be used to guide dose-escalation [17-19]. A study demonstrated that regions of FDG-uptake remained stable during the course of radiotherapy and that the high FDG-uptake regions ( $\geq 50 \%$ maximum standardized uptake value, $S U V_{\max }$ ) in the pretreatment-scan geometrically correlated with residual uptake in the 3-months post-treatment-scan [20]. Furthermore, patients with persisting FDG-uptake within the primary tumour postradiotherapy had a poorer OS compared to patients achieving complete metabolic response [21-23]. Subsequently, we hypothesized that local tumour control can be increased by dose-escalation to 
the areas of high pre-treatment FDG-uptake within the primary tumour (concept of 'dose-painting') as opposed to a homogeneous dose-escalation to the entire tumour volume [24,25].

These considerations led to the design of the international randomized phase II PET-boost trial (NCT01024829), which investigated dose-escalation using an isotoxic hypofractionated schedule either to the entire primary tumour or redistributed to the regions of high pre-treatment FDG-uptake $\left(\mathrm{SUV}_{\max } \geq 50 \%\right)$ within the primary tumour. Here, we present the acute and late toxicity results of the 107 patients randomized in the study.

\section{Material and methods}

\section{Trial protocol and eligibility}

Patients in the PET-boost trial (NCT01024829) were accrued in six hospitals in the Netherlands, Belgium, Denmark, Sweden and the United Kingdom. Patients eligible for registration had pathologically proven inoperable stage II-III NSCLC with a primary tumour diameter $\geq 4 \mathrm{~cm}$ (to allow boosting of a subvolume) and a $\operatorname{SUV}_{\max } \geq 5$ on the pre-treatment FDG-PET-CT-scan. Patients were ineligible if they had prior RT to the chest, tumour invasion in large blood vessels, clinical vena cava superior syndrome or multiple nodules in the same or ipsilateral lobes.

Eligible patients were randomized to receive $\geq 72$ Gy in 24 fractions ( $\geq 3 \mathrm{~Gy} /$ fraction) in 32 days with an integrated boost to the planning target volume (PTV) of the entire primary tumour or only to the regions with a $S U V_{\max } \geq 50 \%$ within the PTV of the primary tumour on the pre-treatment FDG-PET-scan. The maximum boost dose was calculated for each individual patient based on OAR constraints (concept of 'isotoxicity') (Table 1). The dose prescription to involved lymph nodes was not escalated (66 Gy in 2.75 Gy per fraction). Elective nodal irradiation was not permitted. If doseescalation was not possible due to organ at risk (OAR) constraints, the patient was not randomized and the dose delivered was $66 \mathrm{~Gy}$ (in 2.75 Gy fractions) or lower. Chemotherapy was delivered concurrently or sequentially, and RT alone was also allowed.

The primary endpoint of the study is freedom from local failure (FFLF) at 1 year according to Response Evaluation Criteria in Solid Tumours (RECIST 1.1). We hypothesized that dose-escalation and redistribution to regions of high FDG-uptake could improve the 1 -year FFLF from $70 \%$ to $85 \%$. It was calculated $(\alpha=5 \% ; \beta=80 \%$, reported 1-year survival in large volume tumours is around $60 \%$ [26]) that 82 patients per arm were needed to test this hypothesis. Secondary endpoints included acute and late toxicity, overall survival (OS), distant metastases, out-of-field recurrences and quality of life (EORTC-QoL). The study closed for recruitment on the 31 st of October 2017.

\section{FDG-PET-scans, radiotherapy planning and treatment}

Eligible patients underwent a 4D-CT-scan and a pre-treatment 3D FDG-PET-scan within 4 weeks of the RT according to the NEDPAS protocol or EANM guidelines [27]. The subvolume of high FDG-uptake for boosting was the fraction of the volume within the primary tumour with a $\operatorname{SUV}_{\max } \geq 50 \%$.

The delineation of the target volumes and the treatment planning procedure were previously reported by Van Elmpt et al. [28]. The OARs were delineated according to the AmsterdamMaastricht normal tissue atlas (Supplementary material). In addition to the standard thoracic OARs, the mediastinal envelope was delineated to encompass the large blood vessels, the proximal bronchi, the heart and the oesophagus. A planning organ-at-risk volume (PRV) margin of $5 \mathrm{~mm}$ was added to the mediastinal envelope.

During treatment planning, an isotoxic radiation treatment plan was optimized for each arm with an equal mean lung dose (MLD).
In case of overlap between the primary tumour and the PRV, the PTV was underdosed (maximum 15\% of the volume) to meet the dose constraints of the mediastinal envelope (Fig. 1). A maximum dose of $94 \mathrm{~Gy}$ (equivalent dose in $2 \mathrm{~Gy}$ fractions, $\mathrm{EQD}_{2}$ ) in $0.1 \%$ of the volume was allowed in the mediastinal envelope. Setup corrections were performed according to local policy. Replanning was advised in case of significant changes of the anatomy.

\section{Toxicity assessment and dose limiting toxicities (DLT)}

Patients were evaluated weekly during RT to assess toxicity. Toxicity was scored at each visit and defined according to the Common Terminology Criteria for Adverse Events version 3.0 (CTCAEv3.0) for acute and late toxicity: acute toxicity occurring within 90 days from start of RT and late toxicity $\geq 90$ days after the start of RT. Follow-up consisted of appointments 1 and 3 weeks after RT and subsequently every three months until 18 months. Thereafter, patients were followed-up every 6 months until death.

The pre-defined stopping rules were: $\geq 20 \%$ of patients developing a pre-specified $\geq$ grade $3-4$ (G3 or G4) acute and/or late toxicity while the lower bound of the one-tailed $95 \% \mathrm{CI}$ exceeds $10 \%$. The pre-specified stopping rules were defined for oesophageal, pulmonary, skin and haematologic toxicity (Supplementary material). Dysphagia was a combination of 3 adverse events: oesophagitis, mucositis and dysphagia. For patients with progressive disease, it is challenging to distinguish symptoms related to progressive disease to those related to toxicity. Therefore, the late toxicity rates until progression and until death are reported separately. G4 and G5 toxicities were centrally reviewed by the principal investigators and reported to the Independent Data Monitoring Committee (IDMC).

\section{Statistical analysis}

The incidence of toxicity was calculated as a proportion of patients experiencing a specific toxicity calculated for all randomized patients $(N=107)$. Confidence intervals for those proportions were calculated using the exact method. The Mann-Whitney $U$-test was performed to test differences of the prescribed doses to the OARs between the two treatment arms (Table 1). No significant differences were revealed between the 2 arms, except for the brachial plexus, which was only delineated when the tumour was in the upper lobe. The toxicity analyses were performed for both treatment arms combined, however they were presented for concurrent chemotherapy versus sequential chemotherapy/RT alone. Fisher exact test was used to compare toxicity between concurrent chemotherapy versus sequential chemotherapy/RT alone. Analyses were performed for early toxicity versus late. Late toxicity was reported both throughout the entire follow-up period and also until disease progression. Additionally, we calculated the maximum grade of acute and late toxicity per patient. All statistical analyses were done using $\mathrm{R}$ (version 3.3.1).

\section{Results}

Between April 2010 and June 2015, 150 patients were registered of which 107 patients were randomized. Forty-three patients were not randomized due to OAR constraints, the inability to obtain a CTthorax with intravenous contrast, logistical problems or regression of primary tumour diameter after chemotherapy to $<4 \mathrm{~cm}$. The majority of the 107 randomized patients had stage III NSCLC (87\%) and WHO performance status of $0-1$ (91\%). The patient and tumour characteristics are shown in Table 2. cCRT was given to 77 (72\%) patients, RT alone to 20 (19\%) and sCRT to 10 (9\%). Concurrent chemotherapy regimens consisted of daily Cisplatin $\left(6 \mathrm{mg} / \mathrm{m}^{2}\right)$ in 34 patients, 3-weekly Cisplatin $\left(75 \mathrm{mg} / \mathrm{m}^{2} \mathrm{~d} 1\right)$-Etoposide 
Table 1

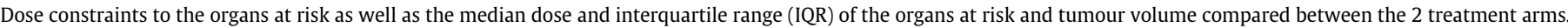

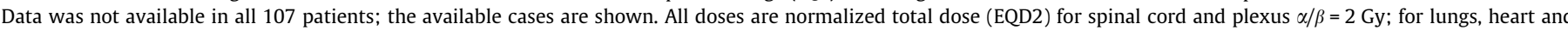
mediastinal envelope $\alpha / \beta=3 \mathrm{~Gy}$ and for the oesophagus $\alpha / \beta=10 \mathrm{~Gy}$.

\begin{tabular}{|c|c|c|c|c|c|}
\hline Organ at risk & Maximum allowed dose & Homogeneous boost (Median, IQR) & Inhomogeneous boost (Median, IQR) & $P$-value & Available cases \\
\hline Brachial plexus (EQD2 2 ) & D0.1\% <79 Gy & $64.2(52.2-65.5)$ & $52.4(14.8-62.1)$ & 0.03 & 53 \\
\hline Oesophagus (EQD2 $\left.2_{10}\right)$ & D0.1\% < $70 \mathrm{~Gy}$ & $65.7(63.9-70.3)$ & $65.4(62.5-70.6)$ & 0.46 & 102 \\
\hline Oesophagus mean dose (EQD2 $\left.{ }_{10}\right)$ & & $23.2(18.4-30.5)$ & $21.7(15.0-30.9)$ & 0.48 & 102 \\
\hline Oesophagus $\left(E Q D 2_{10}\right)$ & $\mathrm{V}_{35}<80 \%$ & $34.7(25.2-46.7)$ & $34.0(16.7-47.3)$ & 0.36 & 101 \\
\hline Heart $\left(E Q D 2_{3}\right)$ & D0.1\% <94 Gy & $67.2(52.5-75.2)$ & $68(35.5-72.6)$ & 0.56 & 74 \\
\hline Heart mean dose & & $8.1(3.1-17.8)$ & $10.9(2.2-16.7)$ & 0.96 & 102 \\
\hline Lung MLD (EQD2 $\left.2_{3}\right)$ & $<20 \mathrm{~Gy}$ & $17.2(14.5-19.2)$ & $16.5(13.0-18.7)$ & 0.25 & 102 \\
\hline Lung V20 & & $24.1(18.3-28.6)$ & $23.8(17.6-31.3)$ & 0.91 & 102 \\
\hline Lung V5 & & $73.2(60.0-86.0)$ & $67.3(50.9-93.2)$ & 0.63 & 102 \\
\hline Mediastinal envelope $\left(\mathrm{EQD} 2_{3}\right)$ & D0.1\% <94 Gy & $90.4(83.7-92.2)$ & $90.8(86.4-92.4)$ & 0.47 & 102 \\
\hline Spinal cord $\left(\mathrm{EQD} 2_{2}\right)$ & D0.1\% <53 Gy & $46.8(41.8-49.1)$ & $48.5(38.0-50.4)$ & 0.40 & 102 \\
\hline \multirow[t]{2}{*}{ Volume (cc) } & GTV tumour & $99(66.5-175)$ & $115(63.5-175.2)$ & 0.98 & 99 \\
\hline & GTV LNs & $17(11-47)$ & $19(9-49)$ & 0.86 & 78 \\
\hline
\end{tabular}

D0.1\% = maximum allowed dose to $0.1 \%$ of the volume of the organ at risk

$\mathrm{V}_{35}=$ the volume of the oesophagus receiving $35 \mathrm{~Gy}$.

GTV $=$ Gross tumour volume.

LNs = Involved lymph nodes

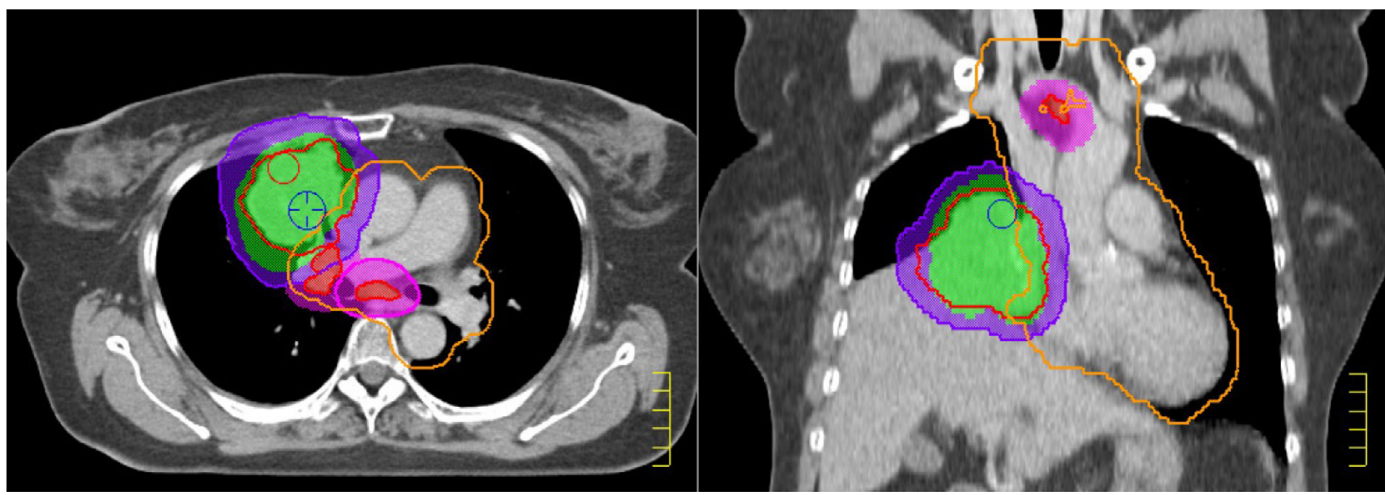

$A-$ Red=gross tumor volume; orange=PRV (mediastinal envelope $+5 \mathrm{~mm}$ margin); pink=planning target volume (PTV) of involved lymph nodes; green=PTV of FDG-avid regions ( $>50 \% \mathrm{SUV}_{\max }$ );

purple=PTV of primary tumor.

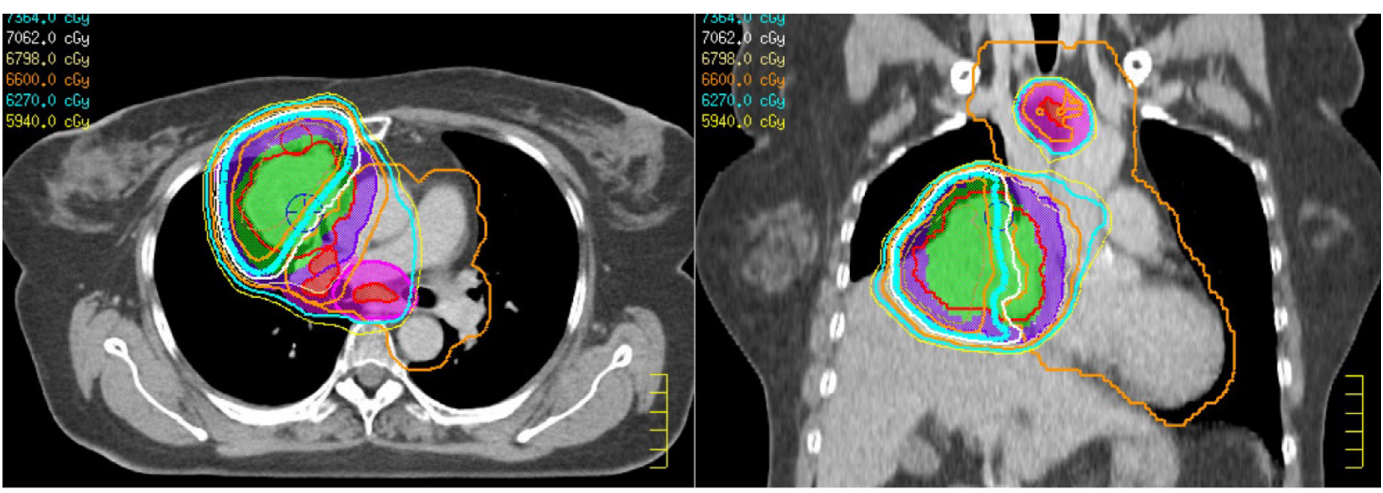

B - Typical dose distribution of a patient treated with a high radiation dose to the whole primary tumor (homogeneous boost). The thick blue line represents the $95 \%$ isodose of the boost dose to the primary tumor; the thin blue line depicts the $95 \%$ isodose of $66 \mathrm{~Gy}$ to the involved lymph nodes. This example shows that a part of the PTV of the primary tumor overlaps with the mediastinal envelope. This part of the PTV is not escalated and receives the conventional dose of the mediastinal envelope.

Fig. 1. Example of treatment planning taking into account the mediastinal envelope. 
Table 2

Baseline patient and tumour characteristics of the 107 randomized patients treated in the PET-boost trial.

\begin{tabular}{|c|c|c|c|}
\hline Characteristic & $\begin{array}{l}\text { Concurrent chemotherapy } \\
N=77(72 \%)\end{array}$ & $\begin{array}{l}\text { Sequential chemotherapy } N=10(9 \%) \\
\text { or RT alone } N=20(19 \%)\end{array}$ & $\begin{array}{l}\text { Total } \\
N=107\end{array}$ \\
\hline $\begin{array}{l}\text { Median age } \\
\text { Gender }\end{array}$ & 64 & 76 & 66 \\
\hline Male & 47 (61\%) & $21(70 \%)$ & $68(64 \%)$ \\
\hline Female & 30 (39\%) & $9(30 \%)$ & $39(36 \%)$ \\
\hline \multicolumn{4}{|l|}{ Performance status } \\
\hline WHO 0 & 35 (45\%) & $5(17 \%)$ & $40(37 \%)$ \\
\hline WHO 1 & $37(48 \%)$ & $22(73 \%)$ & $59(55 \%)$ \\
\hline WHO 2 & $4(5 \%)$ & $3(10 \%)$ & $7(7 \%)$ \\
\hline NA & $1(1 \%)$ & 0 & $1(1 \%)$ \\
\hline \multicolumn{4}{|l|}{ T-stage } \\
\hline $\mathrm{T} 1$ & $1(1 \%)$ & 0 & $1(1 \%)$ \\
\hline $\mathrm{T} 2$ & $29(38 \%)$ & $8(27 \%)$ & $37(35 \%)$ \\
\hline T3 & $20(26 \%)$ & $14(47 \%)$ & $34(32 \%)$ \\
\hline $\mathrm{T} 4$ & $27(35 \%)$ & $8(27 \%)$ & $35(33 \%)$ \\
\hline \multicolumn{4}{|l|}{$N$-stage } \\
\hline No & $9(12 \%)$ & $11(37 \%)$ & $20(19 \%)$ \\
\hline N1 & $5(6 \%)$ & $4(13 \%)$ & $9(8 \%)$ \\
\hline N2 & $52(68 \%)$ & $11(37 \%)$ & $63(59 \%)$ \\
\hline N3 & $11(14 \%)$ & $3(10 \%)$ & $14(13 \%)$ \\
\hline $\mathrm{Nx}$ & 0 & $1(3 \%)$ & $1(1 \%)$ \\
\hline \multicolumn{4}{|l|}{ TNM-stage (\%) } \\
\hline II & $3(4 \%)$ & $10(33 \%)$ & $13(12 \%)$ \\
\hline IIIA & $50(65 \%)$ & $13(43 \%)$ & $63(59 \%)$ \\
\hline IIIB & $24(31 \%)$ & $7(23 \%)$ & $31(29 \%)$ \\
\hline \multicolumn{4}{|l|}{ Histology (\%) } \\
\hline Squamous cell & 27 (35\%) & $14(47 \%)$ & $41(38 \%)$ \\
\hline Adenocarcinoma & $24(31 \%)$ & $9(30 \%)$ & $33(31 \%)$ \\
\hline Large cell carcinoma & $12(16 \%)$ & $4(13 \%)$ & $16(15 \%)$ \\
\hline Not otherwise specified & $14(18 \%)$ & $3(10 \%)$ & $17(16 \%)$ \\
\hline
\end{tabular}

(100 $\left.\mathrm{mg} / \mathrm{m}^{2} \mathrm{~d} 1-3\right)$ in 27 patients and 3-weekly Cisplatin ( $75 \mathrm{mg} / \mathrm{m}^{2} \mathrm{~d} 1$ )-Vinorelbine $\left(60 \mathrm{mg} / \mathrm{m}^{2} \mathrm{~d} 2,8\right)$ in 16 patients. Sequential chemotherapy consisted of Cisplatin-Gemcitabine in 10 patients.

Ninety-six of the 107 patients (90\%) completed the chemotherapy and radiotherapy according to the study protocol. cCRT was terminated in 1 patient after the first fraction due to a transient ischaemic attack (TIA) secondary to hypotension and pneumonia. One patient died secondary to a pulmonary embolism after 2 fractions. In 2 patients, RT was stopped after 23 fractions because in 1 patient the dose constraint to the PRV in 1 patient had been exceeded (due to tumour regression) and the other patient died due to progressive disease. In 3 patients, the concurrent chemotherapy was discontinued due to an allergic reaction, a TIA secondary to hypotension, and thrombocytopenia. Furthermore, in 3 patients the overall treatment time of 32 days was exceeded (Supplementary material). All patients were treated using a daily Cone-Beam CT-scan (CBCT) based set-up procedure.

The median FU was 38 months and 63 out of 107 patients had died. The acute and late toxicity are shown in Table 3. Table 3B and $3 \mathrm{C}$ shows the late toxicity until progression and until death separately. The rate of any G3-5 acute adverse event (maximum grade) per patient was $47 \%$ of the patients in the cCRT-group versus $23 \%$ in the sCRT/RT group, which was statistically significant $(p=0.03)$. G3-5 late toxicity until progression and until death respectively, was observed in $27 \%$ and $43 \%$ in the cCRT-group versus $23 \%$ and $40 \%$ in the sCRT/RT-group, which were not significantly different ( $p=0.81$ and $p=0.83$; Table 3D).

The rate of $\geq \mathrm{G} 3$ acute dysphagia was $14.3 \%$ in patients treated with cCRT compared to $3.3 \%$ in patients treated with sCRT or RT alone ( $p=0.17$ ) (Table 4). Out of the 107 randomized patients, late dysphagia $\geq \mathrm{G} 3$ was reported in $15.6 \%$ treated with cCRT and in $3.3 \%$ of the patients treated with $\mathrm{sCRT} / \mathrm{RT}(p=0.11)$. Two patients developed dysphagia, which started as an acute toxicity and continued as late, but eventually resolved after 6 and 10 months respectively.

Seventeen patients died secondary to a G5 event, of which 5 (4.7\%) patients died within 3 months after completion of the treatment (Table 5). Most common cause of death was pulmonary haemorrhage (5 patients) and an oesophageal fistula (4 patients). Most fatal events developed between 10 and 19 months after treatment, although one patient died after 6 weeks only and another patient after almost 6 years. Patients with fatal pulmonary haemorrhages all had centrally located tumours with encasement of large vessels on the pre-treatment CT-scan. Four patients with a fatal pulmonary haemorrhage had local tumour progression at the time of death and the histology was SCC. The patients that developed G5 fatal pulmonary haemorrhages and fistulae are described in detail in the Supplementary Material.

\section{Discussion}

This analysis presents detailed toxicity data of 107 inoperable NSCLC patients randomized in the PET-boost trial between radiation dose-escalation to the primary tumour or to regions with high FDG-uptake within the primary tumour. The dose to the mediastinal envelope and lymph nodes was not escalated. For each patient individually, the RT dose was escalated to a pre-determined maximum dose to OARs with a fixed overall treatment time. This isotoxic strategy as well as the selection of patients with large primary tumour volumes $(>4 \mathrm{~cm})$ resulted in higher OAR doses. Therefore, a higher toxicity profile was anticipated compared to patients treated with conventionally fractionated schedules. Furthermore, in this study we continued scoring toxicity even after disease progression, which is not commonly performed. 
Table 3

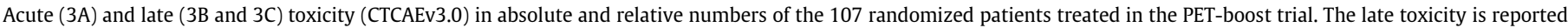

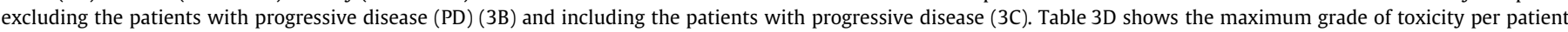

\begin{tabular}{|c|c|c|c|c|c|c|c|c|}
\hline A & G1 & & $\mathrm{G} 2$ & G3 & G4 & G5 & \multicolumn{2}{|c|}{$\begin{array}{l}\geq \mathrm{G} 3(\%) \\
(95 \% \mathrm{CI})\end{array}$} \\
\hline Cough & $52(48.6 \%)$ & & $17(15.9 \%)$ & $3(2.8 \%)$ & 0 & 0 & \multicolumn{2}{|c|}{$2.8(0.6-8.0)$} \\
\hline Dysphagia & $25(23.4 \%)$ & & $42(39.3 \%)$ & $12(11.2 \%)$ & 0 & 0 & \multicolumn{2}{|c|}{$11.2(5.9-18.8)$} \\
\hline Dyspnoea & $39(36.4 \%)$ & & $12(11.2 \%)$ & $4(3.7 \%)$ & 0 & 0 & \multicolumn{2}{|c|}{$3.7(1.0-9.3)$} \\
\hline Fatigue & $39(36.4 \%)$ & & $20(18.7 \%)$ & $2(1.9 \%)$ & $1(0.9 \%)$ & 0 & \multicolumn{2}{|c|}{$2.8(0.6-8.0)$} \\
\hline Haematological & $11(10.3 \%)$ & & $9(8.4 \%)$ & $9(8.4 \%)$ & $4(3.7 \%)$ & 0 & \multicolumn{2}{|c|}{$12.1(6.6-19.9)$} \\
\hline Nausea/vomiting & 17 (15.9\%) & & $17(15.9 \%)$ & $4(3.7 \%)$ & 0 & 0 & \multicolumn{2}{|c|}{$3.7(1.0-9.3)$} \\
\hline Weight loss & $26(24.3 \%)$ & & $17(15.9 \%)$ & $5(4.7 \%)$ & 0 & 0 & \multicolumn{2}{|c|}{$4.7(1.5-10.6)$} \\
\hline Pneumonitis & 0 & & $5(4.7 \%)$ & $2(1.9 \%)$ & 0 & 0 & \multicolumn{2}{|c|}{$1.9(0.2-6.6)$} \\
\hline Pulmonary haemorrhage & $13(12.1 \%)$ & & 0 & 0 & 0 & $2(1.9 \%)$ & \multicolumn{2}{|c|}{$1.9(0.2-6.6)$} \\
\hline Cardiac & $3(2.8 \%)$ & & $1(0.9 \%)$ & $3(2.8 \%)$ & $1(0.9 \%)$ & $2(1.9 \%)$ & \multicolumn{2}{|c|}{$5.6(2.1-11.8)$} \\
\hline Other & $29(27.1 \%)$ & & $35(32.7 \%)$ & $16(15.0 \%)$ & $3(2.8 \%)$ & $1(0.9 \%)$ & \multicolumn{2}{|c|}{$18.7(11.8-27.4)$} \\
\hline B & G1 & & G2 & G3 & G4 & G5 & \multicolumn{2}{|c|}{$\geq \mathrm{G} 3(\%)(95 \% \mathrm{CI})$} \\
\hline Cough & $45(42.1 \%)$ & & $16(15.0 \%)$ & $2(1.9 \%)$ & 0 & 0 & \multicolumn{2}{|c|}{$1.9(0.2-6.6)$} \\
\hline Dysphagia & 15 (14.0\%) & & $12(11.2 \%)$ & $8(7.5 \%)$ & 0 & 0 & \multicolumn{2}{|c|}{$7.5(3.3-14.2)$} \\
\hline Dyspnoea & $27(25.2 \%)$ & & $12(11.2 \%)$ & $7(6.5 \%)$ & $2(1.9 \%)$ & $1(0.9 \%)$ & \multicolumn{2}{|c|}{$9.3(4.6-16.5)$} \\
\hline Fatigue & $29(27.1 \%)$ & & $13(12.1 \%)$ & $2(1.9 \%)$ & 0 & 0 & \multicolumn{2}{|c|}{$1.9(0.2-6.6)$} \\
\hline Haematological & $6(5.6 \%)$ & & $1(0.9 \%)$ & 0 & $1(0.9 \%)$ & 0 & \multicolumn{2}{|c|}{$1.9(0.2-6.6)$} \\
\hline Nausea/vomiting & 7 (6.5\%) & & $2(1.9 \%)$ & $2(1.9 \%)$ & 0 & 0 & \multicolumn{2}{|c|}{$1.9(0.2-6.6)$} \\
\hline Weight loss & $14(13.1 \%)$ & & $7(6.5 \%)$ & $2(1.9 \%)$ & 0 & 0 & \multicolumn{2}{|c|}{$1.9(0.2-6.6)$} \\
\hline Pneumonitis & $6(5.6 \%)$ & & $12(11.2 \%)$ & $5(4.7 \%)$ & 0 & $1(0.9 \%)$ & \multicolumn{2}{|c|}{$5.6(2.1-11.8)$} \\
\hline Pulmonary haemorrhage & 7 (6.5\%) & & 0 & $1(0.9 \%)$ & 0 & 0 & \multicolumn{2}{|c|}{$0.9(0.0-5.1)$} \\
\hline Cardiac & $4(3.7 \%)$ & & $4(3.7 \%)$ & $1(0.9 \%)$ & $1(0.9 \%)$ & 0 & \multicolumn{2}{|c|}{$1.9(0.2-6.6)$} \\
\hline C & G1 & & G2 & G3 & G4 & G5 & \multicolumn{2}{|c|}{$\begin{array}{l}\geq \mathrm{G} 3(\%) \\
(95 \% \mathrm{CI})\end{array}$} \\
\hline Cough & $48(44.9 \%)$ & & $21(19.6 \%)$ & $3(2.8 \%)$ & 0 & 0 & \multicolumn{2}{|c|}{$2.8(0.6-8.0)$} \\
\hline Dysphagia & $19(17.8 \%)$ & & $17(15.9 \%)$ & $11(10.3 \%)$ & $2(1.9 \%)$ & 0 & 12 . & 19.9) \\
\hline Dyspnoea & $29(27.1 \%)$ & & $18(16.8 \%)$ & $8(7.5 \%)$ & $4(3.7 \%)$ & $3(2.8 \%)$ & 14 & $2.1)$ \\
\hline Fatigue & $35(32.7 \%)$ & & $21(19.6 \%)$ & $3(2.8 \%)$ & $1(0.9 \%)$ & 0 & 3.7 & .3) \\
\hline Haematological & $10(9.3 \%)$ & & $2(1.9 \%)$ & $3(2.8 \%)$ & $1(0.9 \%)$ & 0 & 3.7 & .3) \\
\hline Nausea/vomiting & $9(8.4 \%)$ & & $4(3.7 \%)$ & $4(3.7 \%)$ & 0 & 0 & 3.7 & $3)$ \\
\hline Weight loss & $20(18.7 \%)$ & & $11(10.3 \%)$ & $3(2.8 \%)$ & $1(0.9 \%)$ & 0 & 3.7 & .3) \\
\hline Pneumonitis & $6(5.6 \%)$ & & $12(11.2 \%)$ & $6(5.6 \%)$ & 0 & $1(0.9 \%)$ & 6.5 & $3.0)$ \\
\hline Pulmonary haemorrhage & $13(12.1 \%)$ & & 0 & $1(0.9 \%)$ & 0 & $4(3.7 \%)$ & 4.7 & $0.6)$ \\
\hline Cardiac & $5(4.7 \%)$ & & $5(4.7 \%)$ & $2(1.9 \%)$ & $2(1.9 \%)$ & $2(1.9 \%)$ & 5.6 & $1.8)$ \\
\hline Fistula & 0 & & $1(0.9 \%)$ & 0 & 0 & $4(3.7 \%)$ & 3.7 & \\
\hline Other & $22(20.6 \%)$ & & $29(27.1 \%)$ & $29(27.1 \%)$ & $4(3.7 \%)$ & $1(0.9 \%)$ & 31. & $-41.5)$ \\
\hline $\mathrm{D}$ & & G0 & G1 (\%) & $\mathrm{G} 2(\%)$ & G3 (\%) & G4 (\%) & G5 (\%) & Total \\
\hline Maximum grade of acute & & $6(6 \%)$ & $14(13 \%)$ & $44(41 \%)$ & $32(30 \%)$ & $6(6 \%)$ & $5(5 \%)$ & 107 \\
\hline Maximum grade of late to & $1 \mathrm{PD}$ & $28(26 \%)$ & $21(20 \%)$ & $30(28 \%)$ & $23(21 \%)$ & $2(2 \%)$ & $3(3 \%)$ & 107 \\
\hline Maximum grade of late to & & $13(12 \%)$ & $13(12 \%)$ & $36(34 \%)$ & $29(27 \%)$ & $4(4 \%)$ & $12(11 \%)$ & 107 \\
\hline
\end{tabular}

The rates of $\geq \mathrm{G} 3$ acute dysphagia of $14.3 \%$ in patients treated with cCRT and $3.3 \%$ in patients treated with sCRT or RT alone are comparable to those reported in the Auperin meta-analysis [2]. The use of a PRV around the mediastinal envelope and strict dose constraints (accepting that $15 \%$ of the volume of the PTV could be underdosed in order to meet the mediastinal envelope dose constraints) contributed to this outcome. Also, $96 \%$ of the patients treated with cCRT had stage III (versus $66 \%$ in the sCRT/RT-group) and only $12 \%$ had no involved lymph nodes (versus $37 \%$ in the sCRT/RT-group). Nevertheless, the $\geq \mathrm{G} 3$ acute dysphagia rates in the cCRT-group were higher than in the $60 \mathrm{~Gy}$-arm of the RTOG 0617-trial, which reported a rate of $7 \%$ versus $21 \%$ in the $74 \mathrm{~Gy}-$ arm [8]. In the EORTC 08972-22973 phase III trial the same hypofractionated schedule of $66 \mathrm{~Gy}$ in 24 fractions as in the PETboost trial was delivered [5]. Radiation was delivered to the primary tumour and involved lymph nodes, with either concurrent or sequential chemotherapy. The late oesophageal toxicity of this hypofractionated schedule was analysed by Chen et al., who reported that $11(6 \%)$ of 171 patients treated with cCRT developed severe toxicity: 8 patients developed a G3 stenosis and 3 patients a G4 fistula [29]. The volume of the oesophagus receiving $>76.6 \mathrm{~Gy}$ $\left(E Q D 2_{10}\right)$ was significantly correlated with G4 dysphagia, as well as the maximum grade of acute dysphagia and the recovery rate. In the PET-boost trial, 2 patients had prolonged dysphagia that resolved completely. Nevertheless, 4 patients developed an oesophageal fistula that very likely caused their death.

Cannon et al. reported the late G4-5 toxicity results of a prospective phase I-trial of 79 locally advanced NSCLC-patients treated with dose-escalated RT according to Normal Tissue Complication Probability (NTCP)-modelling to predict $\geq \mathrm{G} 2$ pneumonitis [30]. Most of the patients received neoadjuvant or adjuvant chemotherapy, but 25 patients were treated with RT only. The total dose to the primary tumour as well as involved lymph nodes varied between 57 and $85.5 \mathrm{~Gy}$ in 25 fractions. Six patients (7.6\%) developed a late G4-5 toxicity, of which 3 (3.9\%) died due to a G5 pulmonary haemorrhage. Univariate analysis showed that the dose to a small volume ( $3 \mathrm{cc}$ ) of the proximal bronchial tree was significant. The authors estimated a $5 \%$ complication rate after 2 years if the $\mathrm{D}(3 \mathrm{cc})$ was $75 \mathrm{~Gy}$ or higher.

Recently, Ren et al. and Jeter et al. published the preliminary toxicity results of small phase I trials using hypofractionated dose-escalated RT to the tumour and the lymph nodes in stage III NSCLC-patients [31,32]. Both trials used increasing dose levels, starting at $66 \mathrm{~Gy}$ and gradually increased with $3 \mathrm{~Gy}$. Different 
Table 4

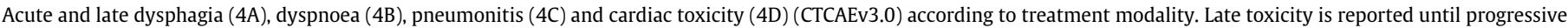
disease (PD) as well as including progression.

\begin{tabular}{|c|c|c|c|c|c|c|}
\hline Acute dysphagia & Grade 1 & Grade 2 & Grade 3 & Grade 4 & Grade 5 & $\geq \mathrm{G} 3$ \\
\hline cCRT & 18 & 34 & 11 & 0 & 0 & $11(14.3 \%)$ \\
\hline sCRT/RT & 7 & 8 & 1 & 0 & 0 & $1(3.3 \%)$ \\
\hline \multicolumn{7}{|l|}{ Late dysphagia until PD } \\
\hline cCRT & 11 & 10 & 7 & 0 & 0 & $7(9.1 \%)$ \\
\hline sCRT/RT & 4 & 2 & 1 & 0 & 0 & $1(3.3 \%)$ \\
\hline \multicolumn{7}{|l|}{ Late dysphagia } \\
\hline cCRT & 14 & 14 & 10 & 2 & 0 & $12(15.6 \%)$ \\
\hline sCRT/RT & 5 & 3 & 1 & 0 & 0 & $1(3.3 \%)$ \\
\hline Acute dyspnoea & Grade 1 & Grade 2 & Grade 3 & Grade 4 & Grade 5 & $\geq \mathrm{G} 3$ \\
\hline cCRT & 27 & 8 & 2 & 0 & 0 & $2(2.6 \%)$ \\
\hline sCRT/RT & 11 & 4 & 2 & 0 & 0 & $2(6.7 \%)$ \\
\hline \multicolumn{7}{|l|}{ Late dyspnoea until PD } \\
\hline cCRT & 22 & 5 & 6 & 1 & 1 & $8(10.4 \%)$ \\
\hline sCRT/RT & 5 & 7 & 1 & 1 & 0 & $2(6.7 \%)$ \\
\hline \multicolumn{7}{|l|}{ Late dyspnoea } \\
\hline cCRT & 22 & 11 & 7 & 2 & 2 & $11(14.3 \%)$ \\
\hline sCRT/RT & 7 & 7 & 1 & 2 & 1 & $4(13.3 \%)$ \\
\hline Acute pneumonitis & Grade 1 & Grade 2 & Grade 3 & Grade 4 & Grade 5 & $\geq \mathrm{G} 3$ \\
\hline cCRT & 0 & 4 & 0 & 0 & 0 & 0 \\
\hline sCRT/RT & 0 & 1 & 2 & 0 & 0 & $2(6.7 \%)$ \\
\hline \multicolumn{7}{|l|}{ Late pneumonitis until PD } \\
\hline cCRT & 6 & 10 & 4 & 0 & 1 & $5(6.5 \%)$ \\
\hline sCRT/RT & 0 & 2 & 1 & 0 & 0 & $1(1.3 \%)$ \\
\hline \multicolumn{7}{|l|}{ Late pneumonitis } \\
\hline cCRT & 6 & 10 & 5 & 0 & 1 & $6(7.8 \%)$ \\
\hline sCRT/RT & 0 & 2 & 1 & 0 & 0 & $1(3.3 \%)$ \\
\hline Acute cardiac toxicity & Grade 1 & Grade 2 & Grade 3 & Grade 4 & Grade 5 & $\geq \mathrm{G} 3$ \\
\hline cCRT & 1 & 1 & 2 & 1 & 2 & $5(6.5 \%)$ \\
\hline sCRT/RT & 2 & 0 & 1 & 0 & 0 & $1(3.3 \%)$ \\
\hline \multicolumn{7}{|c|}{ Late cardiac toxicity until PD } \\
\hline cCRT & 2 & 3 & 1 & 0 & 0 & $1(1.3 \%)$ \\
\hline sCRT/RT & 2 & 1 & 0 & 1 & 0 & $1(3.3 \%)$ \\
\hline \multicolumn{7}{|l|}{ Late cardiac toxicity } \\
\hline CCRT & 3 & 4 & 2 & 1 & 1 & $4(5.2 \%)$ \\
\hline sCRT/RT & 2 & 1 & 0 & 1 & 1 & $2(6.7 \%)$ \\
\hline
\end{tabular}

$N=77$ were treated with $c$ CRT $=$ concurrent chemo-radiotherapy.

$N=30$ were treated with $\mathrm{SCRT}=$ sequential chemo-radiotherapy.

radiation techniques were applied: 3D-RT (Ren) and IMRT/IMPT (Jeter). The latter excluded T4-tumours showing direct invasion of the OARs. Ren reported that out of 12 patients included in the study 5 (41.7\%) developed G3 dysphagia and 3 (25\%) patients developed G3 pneumonitis. In the study by Jeter et al., out of 9 patients treated to $72 \mathrm{~Gy}, 1$ (11.1\%) developed G3 dysphagia and out of 6 patients treated to $78 \mathrm{~Gy}, 2$ developed (33.3\%) $\geq \mathrm{G} 3$ pneumonitis. The respective conclusion of the trials is that the maximum tolerated dose is $69 \mathrm{~Gy}$ in $3 \mathrm{~Gy} /$ fraction and $72 \mathrm{~Gy}$ in $2.4 \mathrm{~Gy} /$ fraction, which correspond for both trials to $74 \mathrm{~Gy}$ EQD2 10 . However, the authors differed in their interpretation: Ren found the results not acceptable and closed the trial, while the fractionation schedule of Jeter is currently under evaluation in a phase 2 trial (NCT01629498). Major differences with our trial were that we did not escalate the dose to the lymph nodes, consolidation chemotherapy was not allowed and the maximum dose to the oesophagus was restricted to $70 \mathrm{~Gy}\left(\mathrm{EQD}_{2,10}\right)$. Furthermore, in the PET-boost trial an isotoxic dose-escalation regimen was applied using IMRT or VMAT in all patients, based on 4D-CT-scan planning and strict constraints to the mediastinal envelope and imaging (matched planning-CT and FDG-PET-CT-scan as well as volumetric image-guidance during treatment).

An incidence of up to $10 \%$ of fatal haemorrhages was estimated when we designed the trial due to the inclusion of large $(\geq 4 \mathrm{~cm})$ and generally centrally located tumour volumes [33,34]. A total of 5 patients (4.7\%) died of a pulmonary haemorrhage (Table 5). Langendijk et al. described an average fatal bleeding risk of $11.3 \%$ in 938 inoperable stage I-III NSCLC patients, treated with RT and/ or brachytherapy (BT) [34]. The majority of patients were treated with RT alone $(N=840)$, using a heterogeneous RT-schedule with $46 \mathrm{~Gy}$ in 23 fractions or $45 \mathrm{~Gy}$ in 20 fractions followed by a boost up to a cumulative dose of $60-70 \mathrm{~Gy}$ in fractions of $2.0-2.5 \mathrm{~Gy}$. Doses varied between 61.6 and $72 \mathrm{~Gy}\left(\mathrm{EQD}_{2}\right)$. Almost half of the 840 patients had centrally located tumours with proven endobronchial tumour in the proximal airways, based on bronchoscopy. In this group, the incidence of a fatal bleeding was significantly higher compared to the patients without endobronchial tumour: $13.1 \%$ versus $4.3 \%(P<0.001)$. The multivariate analysis revealed that localization of the tumour in the upper lobe and hemoptysis prior to RT were significant risk factors for fatal pulmonary haemorrhages. In the PET-boost trial, patients with large and often centrally located tumours were included and were therefore at a higher risk of G5 pulmonary haemorrhage as described above. In our study, all patients with a G5 pulmonary haemorrhage had centrally located tumours as well as encasement of the large vessels. Kong et al. described recently the results of a phase II-trial in which 42 stage II-III patients were treated with RT and weekly Carboplatin-Paclitaxel followed by consolidation chemotherapy 
Table 5

Characteristics of grade 5 acute and late adverse events scored until death of all 107 patients randomized in the PET-boost trial.

\begin{tabular}{|c|c|c|c|c|c|c|c|c|c|c|c|}
\hline $\mathrm{Pt}$ & $\mathrm{AE}^{1}$ & $\begin{array}{l}\text { Treatment } \\
\text { related }\end{array}$ & Interval (mths) & Site $^{2}$ & TNM & $\mathrm{PA}^{3}$ & Localization & $\begin{array}{l}\text { Fraction } \\
\text { dose } \\
(\mathrm{Gy})\end{array}$ & $\begin{array}{l}\text { sCRT/ } \\
\text { cCRT }^{4}\end{array}$ & $\mathrm{PD}^{5}$ & $\begin{array}{l}\text { Locoregional/ } \\
\text { Distant PD }\end{array}$ \\
\hline 1 & Pulmonary embolism & $\begin{array}{l}\text { Not } \\
\text { related }\end{array}$ & $\begin{array}{l}\text { During treatment } \\
\text { (Died after } 2 \\
\text { fractions) }\end{array}$ & RLL & T3N2 & LCC & Central & 3.2 & $\begin{array}{l}\text { CCRT, } \\
\text { CE }\end{array}$ & $\mathrm{NAS}^{6}$ & NAS \\
\hline 2 & Cardiac disorder & Not likely & $\begin{array}{l}\text { During treatment } \\
\text { (Died after } 23 \\
\text { fractions) }\end{array}$ & LUL & T4N1 & $\mathrm{AC}$ & Central & 3.2 & $\begin{array}{l}\text { cCRT, } \\
\text { CE }\end{array}$ & NAS & NAS \\
\hline 3 & Gastro-intestinal bleeding & Not likely & 1.5 & LUL & $\mathrm{T} 2 \mathrm{~N} 2$ & AC & Peripheral & 3.3 & No & NAS & NAS \\
\hline 4 & Pulmonary haemorrhage & Possible & 1.5 & RUL & T4N2 & SCC & Central & 3.2 & $\begin{array}{l}\text { CCRT, } \\
\text { PE }\end{array}$ & Yes & Locoregional \\
\hline 5 & Pneumosepsis & Certain & 3 & LUL & T4N2 & $\mathrm{AC}$ & Central & 3.4 & $\begin{array}{l}\text { CCRT, } \\
\text { CE }\end{array}$ & No & No \\
\hline 6 & $\begin{array}{l}\text { Respiratory insufficiency } \\
\text { due to interstitial lung } \\
\text { disease }\end{array}$ & $\begin{array}{l}\text { Not } \\
\text { related }\end{array}$ & 3 & RUL & T3N2 & SCC & Peripheral & 3.4 & $\begin{array}{l}\text { cCRT, } \\
\text { CE }\end{array}$ & $\begin{array}{l}\text { No, RT } \\
\text { terminated after } \\
\text { first fraction }\end{array}$ & No \\
\hline 7 & Pulmonary haemorrhage & Possible & 7 & RLL & T3N2 & SCC & Central & 3.2 & $\begin{array}{l}\text { cCRT, } \\
\text { CDDP }\end{array}$ & Yes & Both \\
\hline 8 & $\begin{array}{l}\text { Empyema due to fistula in } \\
\text { bronchus }\end{array}$ & Certain & 8 & RLL & $\mathrm{T} 2 \mathrm{~N} 2$ & LCC & Peripheral & 3.3 & $\begin{array}{l}\text { CCRT, } \\
\text { CE }\end{array}$ & Yes & Distant \\
\hline 9 & Fistula trachea-oesophagus & Probable & 9 & RUL & T3N2 & $\mathrm{AC}$ & Central & 3.7 & $\begin{array}{l}\text { cCRT, } \\
\text { CDDP }\end{array}$ & Yes & Distant \\
\hline 10 & Cardiac failure & Possible & 10 & LUL & T3N2 & SCC & Peripheral & 3.5 & $\begin{array}{l}\text { CCRT, } \\
\text { CE }\end{array}$ & Yes & Both \\
\hline 11 & Pulmonary haemorrhage & Possible & 10 & LLL & T4NO & SCC & Central & 3.2 & $\begin{array}{l}\text { cCRT, } \\
\text { CDDP }\end{array}$ & Yes & Distant \\
\hline 12 & Fistula trachea-oesophagus & Probable & 65 & RLL & $\mathrm{T} 2 \mathrm{~N} 2$ & NOS & Peripheral & 3.3 & $\begin{array}{l}\text { CCRT, } \\
\text { PE }\end{array}$ & No & No \\
\hline 13 & Fistula trachea-oesophagus & Certain & 18 & RUL & T4N2 & LCC & Central & 3.4 & $\begin{array}{l}\text { cCRT, } \\
\text { CE }\end{array}$ & Yes & Distant \\
\hline 14 & Pulmonary haemorrhage & Possible & 12 & RUL & T4N2 & NOS & Central & 3.2 & $\begin{array}{l}\text { CCRT, } \\
\text { PE }\end{array}$ & Yes & Locoregional \\
\hline 15 & Respiratory insufficiency & Possible & 18 & RUL & T2NO & $\mathrm{AC}$ & Peripheral & 5.4 & $\begin{array}{l}\text { CCRT, } \\
\text { PV }\end{array}$ & No & No \\
\hline 16 & Pulmonary haemorrhage & Possible & 19 & LLL & T3N1 & SCC & Central & 3.0 & $\begin{array}{l}\text { cCRT, } \\
\text { CDDP }\end{array}$ & Yes & Distant \\
\hline 17 & Congestive heart failure & Possible & 24 & LLL & T4N2 & SCC & Central & 3.5 & $\begin{array}{l}\text { CCRT, } \\
\text { PE }\end{array}$ & Yes & Locoregional \\
\hline
\end{tabular}

\footnotetext{
$1 \mathrm{AE}=$ Adverse Event.

2 Site = Location of the tumour in the lung; RLL = right lower lobe; RUL = right upper lobe; $L U L=$ left upper lobe; LLL = left lower lobe.

3 PA = Pathology; LC = large cell carcinoma; AC = adenocarcinoma; SCC = squamous cell carcinoma; NOS = not otherwise specified.

4 CCRT = concurrent chemo-radiotherapy; $\mathrm{CDDP}=$ low dose Cisplatin; $\mathrm{CE}=$ Cisplatinum-Etoposide; PV = Carboplatin-Vinorelbin; $\mathrm{PE}=\mathrm{Carboplatin}$-Etoposide.

${ }^{5} \mathrm{PD}=$ Progressive Disease.

${ }^{6}$ NAS $=$ Not Assessed.
}

[35]. Replanning was performed after 40-50 Gy and the FDG-avid regions of the tumour $\left(\operatorname{SUV}_{\max } \geq 50 \%\right.$ ) as well as the LNs were boosted to a maximum dose of $86 \mathrm{~Gy}$ in 30 fractions based on a midtreatment FDG-PET-CT-scan. Four G5 pulmonary haemorrhages were observed; these patients all had T4-tumours with some degree of invasion of the great vessels. Nevertheless, the local control was promising with $82 \%$ after 2 years. Urbanic et al. described 2 G5 pulmonary haemorrhages in 21 stage III NSCLCpatients after treatment in several cohorts using an increasing fraction dose concurrently with chemotherapy followed by consolidation chemotherapy [36]. The authors concluded that the MTD was $60 \mathrm{~Gy}$ in 24 fractions of $2.4 \mathrm{~Gy}$. These recent papers show that dose-escalation using integrated boost is feasible, although the suggested schedules differ widely, but may cause severe toxicity at the same time. There is currently no agreement regarding the dose constraints of the airways and blood vessels.

The IDMC recommended a protocol amendment after an interim analysis when 90 patients were included. This included the reassessment of the performance status after chemotherapy, central review of the tumour delineation before randomization and the exclusion of patients with $>50 \%$ encasement of the large vessels by the primary tumour due to the risk of large vessel invasion [37]. The maximum dose to the PRV of the mediastinal envelope of $115 \%$ was adapted from a relative volume percentage of $0.1 \%$ to an absolute volume of $1 \mathrm{cc}$.

In conclusion, the toxicity results of the PET-boost trial revealed that hypofractionated dose-escalation to the primary tumour, but not the lymph nodes, is associated with higher acute and late toxicities compared to conventional chemoradiotherapy. Caution may be warranted for centrally located tumours as well as tumours causing $>50 \%$ encasement of the large vessels. However, the acute and late toxicity rates were within the boundaries of the predefined stopping rules.

\section{Conflict of interest}

None.

\section{Acknowledgement}

The authors received support from the European Commission, 7th Framework Project Grant Agreement nr. 257144, ARTFORCE project; and the Dutch Cancer Society (project number 2010-4675).

The authors acknowledge the members of the Independent Data Monitoring Committee: Prof. Dr. J. Van Meerbeeck, Prof. Dr. P. Van Houtte and Prof. Dr. W. De Neve. 
The authors also acknowledge Prof. Dr. C.C.E. Koning and Dr. A. L.J. Uitterhoeve†, Independent Data Monitors.

\section{Appendix A. Supplementary data}

Supplementary data to this article can be found online at https://doi.org/10.1016/j.radonc.2018.09.019.

\section{References}

[1] Bradley JD et al. Standard-dose versus high-dose conformal radiotherapy with concurrent and consolidation carboplatin plus paclitaxel with or without cetuximab for patients with stage IIIA or IIIB non-small-cell lung cancer (RTOC 0617): a randomised, two-by-two factorial phase 3 study. Lancet Onco 2015;16:187-99.

[2] Auperin A et al. Meta-analysis of concomitant versus sequential radiochemotherapy in locally advanced non-small-cell lung cancer. J Clin Oncol 2010;28:2181-90.

[3] Schaake-Koning $C$ et al. Effects of concomitant cisplatin and radiotherapy on inoperable non-small-cell lung cancer. N Engl J Med 1992;326:524-30.

[4] Mauguen A et al. Hyperfractionated or accelerated radiotherapy in lung cancer: an individual patient data meta-analysis. J Clin Oncol 2012;30:2788-97.

[5] Belderbos J et al. Randomised trial of sequential versus concurrent chemoradiotherapy in patients with inoperable non-small cell lung cancer (EORTC 08972-22973). Eur J Cancer 2007:43:114-21.

[6] Senan S et al. PROCLAIM: randomized phase III trial of pemetrexed-cisplatin or etoposide-cisplatin plus thoracic radiation therapy followed by consolidation chemotherapy in locally advanced nonsquamous non-small-cell lung cancer. Clin Oncol 2016;34:953-62.

[7] Walraven I et al. Long-term follow-up of patients with locally advanced nonsmall cell lung cancer receiving concurrent hypofractionated chemoradiotherapy with or without cetuximab. Radiother Oncol 2016;118:442-6.

[8] Bradley, J.D.E.A. Long-term results of RTOG 0617. 2017; Available from: www astro.org/uploadedFiles/_MAIN_SITE/News_and_Publications/News_and_ Media_Center/Press_Kits/2017/Annual_Meeting/Content_Pieces/ASTR017\% 20Briefing\%20Slides_Bradley.pdf

[9] De Ruysscher D et al. Selective mediastinal node irradiation based on FDG-PET scan data in patients with non-small-cell lung cancer: a prospective clinical study. Int J Radiat Oncol Biol Phys 2005;62:988-94.

[10] Schytte T et al. Pattern of loco-regional failure after definitive radiotherapy for non-small cell lung cancer. Acta Oncol 2014;53:336-41.

[11] van Diessen JN et al. Differential analysis of local and regional failure in locally advanced non-small cell lung cancer patients treated with concurrent chemoradiotherapy. Radiother Oncol 2016;118:447-52.

[12] Van den Bosch L et al. Is there a different dose-effect relation between the primary tumor and involved lymph nodes in locally advanced non-small-cell lung cancer? A hypothesis-generating study. Acta Oncol 2017;56:541-7.

[13] van Baardwijk A et al. Individualized radical radiotherapy of non-small-cel lung cancer based on normal tissue dose constraints: a feasibility study. Int J Radiat Oncol Biol Phys 2008;71:1394-401.

[14] Nielsen TB et al. Inhomogeneous dose escalation increases expected local control for NSCLC patients with lymph node involvement without increased mean lung dose. Acta Oncol 2014;53:119-25.

[15] Kong FM et al. High-dose radiation improved local tumor control and overall survival in patients with inoperable/unresectable non-small-cell lung cancer: long-term results of a radiation dose escalation study. Int J Radiat Oncol Bio Phys 2005;63:324-33.

[16] Reymen B et al. Long-term survival of stage T4NO-1 and single station IIIA-N2 NSCLC patients treated with definitive chemo-radiotherapy using individualised isotoxic accelerated radiotherapy (INDAR). Radiother Oncol 2014;110:482-7.
[17] Feng $\mathrm{M}$ et al. Using fluorodeoxyglucose positron emission tomography to assess tumor volume during radiotherapy for non-small-cell lung cancer and its potential impact on adaptive dose escalation and normal tissue sparing. Int J Radiat Oncol Biol Phys 2009;73:1228-34.

[18] Abramyuk A et al. Is pre-therapeutical FDG-PET/CT capable to detect high risk tumor subvolumes responsible for local failure in non-small cell lung cancer? Radiother Oncol 2009;91:399-404.

[19] Lee P et al. Current concepts in F18 FDG PET/CT-based radiation therapy planning for lung cancer. Front Oncol 2012;2:71.

[20] Aerts HJ et al. Stability of 18F-deoxyglucose uptake locations within tumor during radiotherapy for NSCLC: a prospective study. Int J Radiat Oncol Biol Phys 2008:71:1402-7.

[21] Aerts $\mathrm{HJ}$ et al. Identification of residual metabolic-active areas within individual NSCLC tumours using a pre-radiotherapy (18)FluorodeoxyglucosePET-CT scan. Radiother Oncol 2009;91:386-92.

[22] Machtay M et al. Prediction of survival by [18F]fluorodeoxyglucose positron emission tomography in patients with locally advanced non-small-cell lung cancer undergoing definitive chemoradiation therapy: results of the ACRIN 6668/RTOG 0235 trial. J Clin Oncol 2013;31:3823-30.

[23] Usmanij EA et al. Update on F-18-fluoro-deoxy-glucose-PET/computed tomography in nonsmall cell lung cancer. Curr Opin Pulm Med 2015;21:314-21.

[24] Bentzen SM. Dose painting and theragnostic imaging: towards the prescription, planning and delivery of biologically targeted dose distributions in external beam radiation oncology. Cancer Treat Res 2008;139:41-62.

[25] Petit SF et al. Metabolic control probability in tumour subvolumes or how to guide tumour dose redistribution in non-small cell lung cancer (NSCLC): an exploratory clinical study. Radiother Oncol 2009;91:393-8.

[26] Ball D et al. Effect of tumor size on prognosis in patients treated with radical radiotherapy or chemoradiotherapy for non-small cell lung cancer. An analysis of the staging project database of the International Association for the Study of Lung Cancer. J Thorac Oncol 2013;8:315-21.

[27] Boellaard $\mathrm{R}$ et al. The Netherlands protocol for standardisation and quantification of FDG whole body PET studies in multi-centre trials. Eur J Nucl Med Mol Imaging 2008;35:2320-33.

[28] van Elmpt W et al. The PET-boost randomised phase II dose-escalation trial in non-small cell lung cancer. Radiother Oncol 2012;104:67-71.

[29] Chen C et al. Severe late esophagus toxicity in NSCLC patients treated with IMRT and concurrent chemotherapy. Radiother Oncol 2013;108:337-41.

[30] Cannon DM et al. Dose-limiting toxicity after hypofractionated dose-escalated radiotherapy in non-small-cell lung cancer. J Clin Oncol 2013;31:4343-8.

[31] Ren XC et al. Accelerated hypofractionated three-dimensional conformal radiation therapy ( $3 \mathrm{~Gy} /$ fraction) combined with concurrent chemotherapy for patients with unresectable stage III non-small cell lung cancer: preliminary results of an early terminated phase II trial. BMC Cancer 2016;16:288.

[32] Jeter MD et al. Simultaneous integrated boost for radiation dose escalation to the gross tumor volume with intensity modulated (photon) radiation therapy or intensity modulated proton therapy and concurrent chemotherapy for stage II to III non-small cell lung cancer: a phase 1 study. Int J Radiat Oncol Biol Phys 2018;100:730-7.

[33] Lee CB et al. Late complications of high-dose (>/=66 Gy) thoracic conformal radiation therapy in combined modality trials in unresectable stage III nonsmall cell lung cancer. J Thorac Oncol 2009;4:74-9.

[34] Langendijk JA et al. Massive haemoptysis after radiotherapy in inoperable nonsmall cell lung carcinoma: is endobronchial brachytherapy really a risk factor? Radiother Oncol 1998;49:175-83.

[35] Kong FM et al. Effect of midtreatment PET/CT-adapted radiation therapy with concurrent chemotherapy in patients with locally advanced non-small-cell lung cancer: a phase 2 clinical trial. JAMA Oncol 2017;3:1358-65.

[36] Urbanic JJ et al. Phase 1 study of accelerated hypofractionated radiation therapy with concurrent chemotherapy for stage III non-small cell lung cancer: CALGB 31102 (Alliance). Int J Radiat Oncol Biol Phys 2018;101:177-85.

[37] Han CB et al. Pulmonary artery invasion, high-dose radiation, and overal survival in patients with non-small cell lung cancer. Int J Radiat Oncol Biol Phys 2014;89:313-21. 